\title{
Conceptual Specific of Project Management of Regional Economy Development
}

\author{
Vladimir Ivanovich Zarubin ${ }^{1}$, Edward Kitovich Tkhakushinov ${ }^{1}$, Saida Kazbekovna Kuizheva ${ }^{1}$, Svetlana \\ Olegovna Nekrasova ${ }^{1} \&$ Tatiana Anatolievna Ovsyannikova ${ }^{1}$ \\ ${ }^{1}$ Maikop State Technological University, Russian Federation \\ Correspondence: Vladimir Ivanovich Zarubin, Pervomayskaya str., 191, Maikop, Republic of Adygea, 385000, \\ Russian Federation.
}

Received: November 20, 2014

Accepted: February 20, 2015 Online Published: May 22, 2015

doi:10.5539/ass.v1 $1 \mathrm{n} 14 \mathrm{p} 306$

URL: http://dx.doi.org/10.5539/ass.v11n14p306

\begin{abstract}
The process of social and economic systems management including the system of innovative development of a region as a set of programs and projects realized in a region is analyzed in the article. It is assumed that functioning of this system may be optimized by the system of regional management. The choice of special management technologies supports forming and effective realization of project set of innovative space. As program and project set in a region is variable and unbalanced by a number of characteristics this set or system may be defines as a sort of dissipative structure.
\end{abstract}

Keywords: management process, social and economic systems, programs, projects, development of a region

\section{Introduction}

Social and economic programs today are main tool of solving the problem of strategic development of regions. These programs are in essence complexes of program and project steps correlated in terms of realization, resources, executors that form the system of social and economic projects interested not only for a certain economic subjects but for a system of regional management as a whole, for local communities, all the population of a region.

Methodologically verified usage of project management principles on meso-economic level allows optimizing processes of distribution and usage of regional and organizational resources, to focus them on the core directions of strategic development. Project management is now effective instrument supporting transition of regional economy to innovative type and presupposes rational utilization of not only natural territorial and financial resources but of scientific and intellectual potential. So the necessity arises to develop methodology of forming and realization of project management engine that is naturally embedded in regional management system that broaden functional and tool diversity of regional management system. Universally recognized imperative in this domain is priority of modernization of regional management engine. Modernization of management engine is in turn impossible without understanding of structural and functional characteristics of management engine in the context of modern methodological approaches (system, process-driven, projection-based, etc.)

In the context of model representation of a region as complex structural dynamic system of programs and projects management should be supported with diverse toolkit adaptive both in the structure and compound that corresponds to existing system features and tasks.

Well-known researchers Barnes and Wearne noted the necessity and growing requirement in development of model and toolkit in complex projects management (Barnes \& Wearne, 1993). Still scientific and methodological mechanism of management of such system is not yet developed and project management as such is realized in micro-level (in the scope of separate enterprises and organizations). As for regional and territorial levels management of the set of programs and projects is conducted on the base of traditional technologies based on administrative approaches that do not account neither for specific of economic development processes behaviour nor innovative specifics of projects. Today management of innovative program and project system is in essence reduced to monitoring of local processes of realization of separate programs and projects at best, and to collection of parametric information on organization and realization of innovative projects and programs of manufacturing plants and scientific and educational organizations in a region, at worst. So there is no system 
approach in management of the set of programs and projects with innovative specifics in regional social and economic space.

\section{Methods}

\subsection{Theory}

Basing on known approaches to identifying the essence of a project as an object of research it is presupposed to account for two essential components: system and process in interpretation of the concept of project (Liberzon, 2010). On one hand it is a system of correlated and adjusted with resources and termsof steps and actions. On the other hand one cannot but account for the aspect of realization that reveals both the process of realization, executing of these actions that leads to achievement of set aims. It is also rational to consider third dimension of conceptual content of a project. Basing on the principle of system hierarchy (any system is sub-system of higher level system) a project should be viewed as sub-system of a program, strategy, process of development of social and economic system, etc. (Zernadze, 2000).

Management of a set of programs and projects in a region should provide for correlation of ideas, resources used, effects of project and programs with analogous reference points and indicators that were stated in development strategy of a region (Inshakov, 2003). It is caused by the necessity to support grounded funding from regional budget in the scope of three-years plan. Besides, applying regional strategy as the basis of management of a set of programs and projects allows working out organizational and economic foundation to sign contracts between subjects of the process of realization of programs and projects.

To our mind project set may be classified basing on the level of the owner of a project and place of its realization (macro, meso and microlevel; region, municipal unit, organization in wide sense). Neat logical level is related to the source of financing: federal, regional, municipal, organizational or combined budget. Not the less important criterion of classification is the area of project realization: social, economic, financial, ecological, technological, organizational, informational. Intermediate level of classification is related to the industry where project is being realized. Industrial specifics define not only requirements to the content of the project but methods of its prospective profit calculation. In essence, projects of any higher level of hierarchy may relate to this or that area or industry. It is also practical to address in classification multiplicity of project's targets: one-purpose or multi-purpose projects. Number of targets achieved as a result of a project defines multiplicity and complexity of project's tasks.

Specifics of approaches to management of a set of programs and projects as dissipative system is reflected in comparative analysis of concepts of social and economic systems management process and consequently management of the set of programs and projects of a region (see Table 1) (Medvedeva, 2008).

Table 1. Comparative analysis of concepts of social and economic systems management

\begin{tabular}{|c|c|c|}
\hline \multirow{2}{*}{$\begin{array}{c}\text { Dissipative } \\
\text { characteristics of } \\
\text { management process }\end{array}$} & \multicolumn{2}{|r|}{ Conceptual ideas of management process } \\
\hline & Traditional & Modern \\
\hline $\begin{array}{l}\text { Determinancy of } \\
\text { processes and events }\end{array}$ & $\begin{array}{l}\text { Management process has } \\
\text { linear character, toolset is } \\
\text { unified }\end{array}$ & $\begin{array}{l}\text { Non-linear management process due to multilayer character of } \\
\text { management process; toolset is represented by varying set of } \\
\text { decision making ways, methods and technologies }\end{array}$ \\
\hline Chaos & $\begin{array}{l}\text { Absolute silos, toolset are } \\
\text { adaptive }\end{array}$ & $\begin{array}{l}\text { Has hidden structure in most cases qualitatively definable in the } \\
\text { scope of successive technological style of decision making }\end{array}$ \\
\hline Chaos and order & Opposite to each other & Synthesizes cooperation \\
\hline Bifurcational processes & $\begin{array}{l}\text { Ignored or considered the } \\
\text { factors of low importance in } \\
\text { the processes of decision } \\
\text { making }\end{array}$ & $\begin{array}{l}\text { Are fundamental features of management process, caused by its } \\
\text { multilayer character and dynamic character of realization }\end{array}$ \\
\hline $\begin{array}{l}\text { Insignificant } \\
\text { fluctuation }\end{array}$ & $\begin{array}{l}\text { Unable to } \begin{array}{r}\text { impact } \\
\text { development } \\
\text { significantly }\end{array} \\
\text { trajectory }\end{array}$ & $\begin{array}{l}\text { Able to change development trajectoryin the scope multivector } \\
\text { programs and projects }\end{array}$ \\
\hline Synergism & $\begin{array}{l}\text { Ignored or considered the } \\
\text { factors of low importance }\end{array}$ & $\begin{array}{l}\text { Are fundamental features of management process, achieved by } \\
\text { complementary adaptive organizing of management process, } \\
\text { technologies and tools providing it, by compound and structure of } \\
\text { resources, dedicated to realization of multivector programs and } \\
\text { projects. }\end{array}$ \\
\hline Management style & Authoritarian & $\begin{array}{l}\text { Democratic, but still underdeveloped even in theory in part of } \\
\text { methods, tools and managerial decision making support } \\
\text { technologies usually realized by projects and programs }\end{array}$ \\
\hline
\end{tabular}




\subsection{Features of a Set of Programs and Projects}

Non-stable and unbalanced character is typical for innovative set of system program and projects that cause significant level of entropy of processes of forming and realization of innovative programs and projects. The concept "entropy" (the measure of uncertainty of a state) characterizes uncertainty of functioning of any system, including social and economic micro and macro-system (Chalenko, http://kapital-rus.ru/articles/article/211036.) by different indicators and parameters. This is true for analyzed system set.

Unbalanced character of a set of programs and projects may be explained by uninterruptable changing of its parametric characteristics and in the sense of structural forms and resource balance between separate subsets. Processes of development of programs and projects and their realization are unbalanced in time and regional space. According to research of I. Prigogine this feature causes not only the processes of organization and self-organization but chaotic behaviour of a system (entropy is the measure of chaos) in nature, economic and society (Ilya Prigogine, Isabelle Stengers, 1984).

In respect to project management in regional economy entropy is proposed to be viewed as quantitative indicator of irregularity, the measure of extra work to achieve the target or share of non-useful processes and phenomena added to some activity (Cockshott \& Wright, http://left.ru/2009/2/cockshott184.phtml). It means that irregular and uncontrolled activity in realization even high effective separate projects without connection with strategic development context may lead to negative phenomena in regional social and economic environment: misbalance in reproductive and environmental areas, social discontent and other negative results. So described features cause the necessity to realize managerial impacts in the scope of special system of management of a set of programs and projects. Technologies, analytical and methodological tools should be adaptive to support noted features of analyzed innovation oriented social and economic system in the process of management.

Management of a set of programs and projects in a region should provide for alignment of targets, used resources, effects of programs and projects with analogous reference points and indicators declared in regional development strategy. It is caused by the necessity to support grounded usage of budgets of a region in the scope of relevant period of planning process (Zarubin \& Tkhakushinov, 2014). Besides, using of regional development strategy as a basis for management of a set of programs and projects allows forming social and economic foundation for signing contracts between the subjects of process of programs and projects realization. Strategic targets of a region sometimes are interpreted as intentions that define extension of possibility space of territorial system and directions of its development that should be kept for long period (Shekhovtseva, 2008). So strategic dominants in process of management of a set of programs and projects are defined by strategic imperatives or conceptual approaches to the process of region's development (see Table 2).

Table 2. Strategic determinants of a process of programs and projects management in a region

\begin{tabular}{lll}
\hline $\begin{array}{l}\text { Target functions of program and } \\
\text { project management }\end{array}$ & $\begin{array}{l}\text { Strategic targets of management of a set } \\
\text { of programs and projects }\end{array}$ & Managerial impact \\
\hline $\begin{array}{l}\text { Structural changes of a set of } \\
\text { programs and projects }\end{array}$ & $\begin{array}{l}\text { Provisioning for high rate of domestic } \\
\text { regional product growth }\end{array}$ & $\begin{array}{l}\text { External and internal sources of investments, } \\
\text { subject community }\end{array}$ \\
\hline $\begin{array}{l}\text { Development of strategic } \\
\text { advantages, accumulating of } \\
\text { human capital }\end{array}$ & $\begin{array}{l}\text { Growth of competitiveness of regional } \\
\text { reproductive }\end{array}$ & $\begin{array}{l}\text { Local interactions with subjects of } \\
\text { management of subsystems of regional } \\
\text { reproductive complex }\end{array}$ \\
\hline $\begin{array}{l}\text { Technology modernization, } \\
\text { competition stimulation, } \\
\text { deployment of innovations }\end{array}$ & Increase of efficiency of production & $\begin{array}{l}\text { Information communication development, } \\
\text { information space and external connections } \\
\text { set growth }\end{array}$ \\
\hline $\begin{array}{l}\text { Growth of innovations } \\
\text { distribution rate, provisioning } \\
\text { for continuity of development }\end{array}$ & $\begin{array}{l}\text { Economic development alignment, } \\
\text { technological } \\
\text { reproductive complex }\end{array}$ & $\begin{array}{l}\text { Interactions of reproductive industries, } \\
\text { development of growth focal points and } \\
\text { channels }\end{array}$ \\
\hline $\begin{array}{l}\text { Transactional costs reduction } \\
\text { Territorial diffusion of }\end{array}$ & $\begin{array}{l}\text { Optimization of spacial distribution of a } \\
\text { set of programs and projects }\end{array}$ & $\begin{array}{l}\text { Spacial interactions with regard for limited } \\
\text { local resources }\end{array}$ \\
\hline $\begin{array}{l}\text { innovations } \\
\text { Aglomeration effects increase }\end{array}$ & $\begin{array}{l}\text { Spacial interactions, development of growth } \\
\text { focal points and channels }\end{array}$ \\
\hline
\end{tabular}

\subsection{Methods of Management of Programs and Projects in a Region}

Shevchenko I. K. Noted that "strategy should define both concept and priorities of development - target reference point of management, and action program - plans, programs, projects - management tools, as well as 
act as a foundation of management process in long-term and short-term perspective. In this context effectiveness of management process is determined by complex of resources, methods and technologies that support decision making process." (Shevchenko, 2009). Many authors point out correlation between strategy and effective management of programs and projects (Meskendahl, 2010; Rodrigues \& Williams, 1997). Some authors suggest to consider project success criteria from the point of view of critical success factors (Turner, 1994; MorrisPWG. 2000). Development of theoretical and practical conclusions has ledto development of the Perfection model (Westerweld, 2003). In our research we take a priori as prerequisite thesis that all programs and projects developed and realized in a region are defined. But this thesis may be not completely correct. It may be partially explained by a certain degree of spontaneity of development of innovative programs and projects, unstable and changeable character of a set of programs and projects. In this regard strategy only focuses unstable set of programs and projects in the space of regional determinants. This focus is relatively flexible because management of development and progress of system of projects and programs is mainly carried out in decentralized manner. In this case it is senseless to speak about the necessity of centralization of management process (Elazar, 1991). At the same time in management for example national projects, some part of regional and industry-specific programs and projects methods of direct management may be used. On other cases direct management is impossible (organization make decisions on development of innovative projects and programs) and management may be conducted only indirectly via setting starting conditions (development of infrastructure, forming of institutional environment, etc.).

Transition to program management method based on the system of programs and projects is aimed on improvement of existing system of innovative economy management. Programs are the foundation of budgetary policy carried out by the state that is oriented on realization of the most important tasks of development of activities of economy sectors of a region. Programs are separated by the extent of importance in accordance with assigned status in federal, president, regional, sectorial, object target programs and projects. Regional and sectorial programs depending on importance may be assigned status of federal. Federal target programs (FTP) are the most important instrument of realization of structural policy of the state, active impact on economic processes to achieve final social and economic results.

Methodology of management of targeted complex programs including managing investments supporting transitional period is rather poorly developed. Applying and deepening of experience got during the work with methods of investment projects management is important direction of its improvement. From this point of view programs may be viewed as a set of projects forming single multi-project.

It may be reasonable to interpret a set of programs and projects as chaotic movement of dissipative system in the boundaries of some territory. Characterizing movement of dissipative systems I. Prigogine noted "Phase trajectory behaviour in the sense of stability demonstrate that there are some main types of this movement when all the solutions of the system eventually focus on a certain subset. This subset is called «attractor" (Ilya Prigogine, Isabelle Stengers, 1984). Management of a set of programs and projects is in essence reduced to working out impacts that define entropy level (uncertainty level) of analyzed system. Conceptual scheme of management of a set of programs and projects of a region is shown in Figure 1.

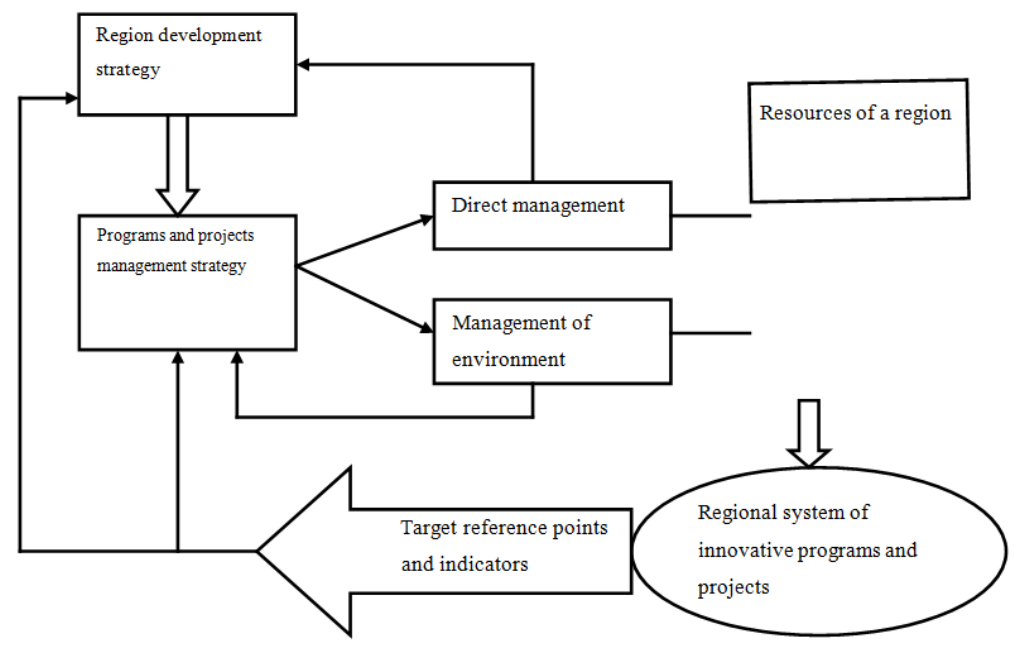

Figure 1. Conceptual scheme of management of system of programs and projects of a region 
This system of control actions should have the following main characteristics and features: orientation on innovations; provisioning for long-term effects and relative stability in strategic direction; order (justice) in usage of regional resources; access to information resources of a region and economy subjects (Ilya Prigogine, Isabelle Stengers, 1984).Taking it into consideration the process of management of innovative-oriented system of programs and projects may be interpreted as a number of steps that provide trajectory of development of a set of programs and projects that comply with strategic priorities.

\subsection{Program-Based Modular Approach to Management of a Set of Programs and Projects}

Economic stability and effectiveness of management of complex systems is followed by growth of structural organization of the system, growth of the number of quantitative characteristics, constant necessity to adapt to external environment. Adaptation of system structure in the scope of management process presupposes growth of activity aimed on improvement of its internal environment that in turn supports achieving balance between the system and its external environment (Gumerova, 2008).

Enhancement of efficiency of managerial decision making and realization in program and project's dimension requires the following:

-development of adaptive decision making algorithms and programs for a system as a whole and its separate subsystems;

-functions identification and alignment of interests of managerial process members, structural subsystems in the context of unidirectional definition of objectives;

-working out programs and projects of effective functioning of subsystems in complex economic environment, adaptation of tools of these programs and projects to management process.

Solving of these tasks in management of meso-economic systems may be achieved in the scope of program-based modular approach based on research of complex systems and including complex of methods of system structuring, modeling interaction between separate subsystems-modules in decision making process and realization of managerial decisions, development of programs and mechanisms of improvement of subsystems' activity in the scope of a certain vector of development of a system as a whole.

Program-based modular approach that is conceptually based on methodological approaches described earlier allows solving the following managerial tasks arousing due to specific features of social and economic systems (Stepanov, 2010):

-structuring of management process to define basic, service and intermediate modules as a bearers of system features. Improved control of these features in the context of preset development direction allows increasing effectiveness of decision making;

-analysis and algorithmization of managerial functions for a system as a whole and separate modules;

-development of target functions, programs and projects after their realization on the base of hierarchy analysis methods;

-transformation of structure of decision making and realization including development of adaptive structures of management;

-development of analytical tools to analyze functioning of improved system structure in management context.

Analysis of program-based modular approach as synthesis of managerial approaches and methods that support management process allows representing this approach in compilation with other approaches, methods and technologies of management as a table (see Table 3).

Table 3. Conceptual and methodological basis of modular approach to tool and technology support of economic systems management process

\begin{tabular}{llll}
\hline $\begin{array}{l}\text { Management } \\
\text { process functions }\end{array}$ & Basic approach/method & $\begin{array}{l}\text { Domain of basic method } \\
\text { application }\end{array}$ & $\begin{array}{l}\text { Range of application of program-based } \\
\text { modular approach }\end{array}$ \\
\hline Goal-setting & $\begin{array}{l}\text { Program-based, } \\
\text { hierarchy analysis } \\
\text { method }\end{array}$ & $\begin{array}{l}\text { Formalization of target } \\
\text { functions, their detalization and } \\
\text { strategic alignment }\end{array}$ & $\begin{array}{l}\text { Synthesis of target functions of main } \\
\text { subsystems by setting correlative links } \\
\text { with final aim of management }\end{array}$ \\
\hline Organization & $\begin{array}{l}\text { Project-based, } \\
\text { process-based }\end{array}$ & $\begin{array}{l}\text { Forming and workig out main } \\
\text { measures, aligned by terms and }\end{array}$ & $\begin{array}{l}\text { Complementary adaptive design of main } \\
\text { processes in modules and system as a }\end{array}$ \\
\hline
\end{tabular}




\begin{tabular}{|c|c|c|c|}
\hline & & $\begin{array}{l}\text { resources, integrated into target } \\
\text { function }\end{array}$ & whole \\
\hline Scheduling & $\begin{array}{l}\text { Structural } \\
\text { functional }\end{array}$ & $\begin{array}{lr}\text { Processes } & \text { structure } \\
\text { identification, } & \text { resources } \\
\text { optimization } & \end{array}$ & $\begin{array}{l}\text { Resources distribution depending on } \\
\text { potential and capacity of realization of } \\
\text { target functions by modules and system as } \\
\text { a whole }\end{array}$ \\
\hline Regulation & Program and targeted & $\begin{array}{l}\text { Forming of control impacts on } \\
\text { the base of usage of different } \\
\text { resources depending on target } \\
\text { purpose }\end{array}$ & $\begin{array}{l}\text { Control impacts modeling, redistribution } \\
\text { and reinvestment of resources and effects } \\
\text { of their usage }\end{array}$ \\
\hline Interaction & Synergetic & $\begin{array}{l}\text { Complex usage of resources, } \\
\text { interrelation of staps and objects } \\
\text { of decision making }\end{array}$ & $\begin{array}{l}\text { Distribution of resources and effects of } \\
\text { their usage with account for poentials of } \\
\text { modules and their synthesis in the process } \\
\text { of decision making }\end{array}$ \\
\hline Realization & Project and process & $\begin{array}{l}\text { Combination of process and } \\
\text { project tools to provide } \\
\text { uninterruptable and effective } \\
\text { management process }\end{array}$ & $\begin{array}{l}\text { Combination of process and project tools } \\
\text { of realization of target functions of } \\
\text { modules and aggregating of effects in } \\
\text { complex result of management process }\end{array}$ \\
\hline Innovation & Project & $\begin{array}{l}\text { Development of perspective } \\
\text { decisions by forming relatively } \\
\text { independent projects and } \\
\text { programs }\end{array}$ & $\begin{array}{l}\text { Multi-vector orientation of projects on } \\
\text { the base of flexible combination of } \\
\text { resources and executive modules }\end{array}$ \\
\hline Control & Cybernetic & Feedback provisioning & Step by step feedback provisioning \\
\hline
\end{tabular}

\section{Results and Discussion}

Algorithmization of management process as integral part of research and development of effective model and structure of decision making and realization process is most fully represented by tools of strategic management. Realization of project-based approach to management in a region is related to the necessity of solving numerous tasks that presuppose analysis of a number of projects in the context of their content, terms and steps, requirement of different types of resources; alignment of made decisions by directions, intensity and time characteristics. Complicated and multidimensional character of these tasks defines the necessity to apply the potential of modern computer technologies that requires relevant formalized representation. Representation of processes of realization and management of projects in multidimensional spaces of signs may be the base of such representation. Space of signs is defined by the set of the most important parameters for a certain task and object characteristics (project in our case) as well as the way to correlate objects with each other. One of the most valuable characteristics on project-based approach is time. We distinguish between three possible ways of developing of space of signs and, respectively, formal descriptions of realization of project approach to regional systems management depending on the way of time factor considering.

Management of a set of programs and projects in a region should provide for alignment of aims, used resources, effects of projects and programs with the same reference points and indicators declared in regional strategy of development. It is caused by the necessity to provide for grounded usage of regional budget in the scope of relevant period of planning process. Besides, using regional strategy as a basis of management of a set of programs and projects allows developing organization and economic foundation to sign contracts between the subjects of the process of programs and projects realization.

As mentioned earlier a set of programs and projects in a region is dissipative system that is unstable in time and space of the structure with elements linked not by durable horizontal but by loose vertical links. At the same time this system is characterized by integrated potential, including economic, social, ecological, reproductive, innovative and other elements.

\section{Realization of Project-Based Approach to Management in a Region}

Realization of project-based approach to management in a region is related to the necessity to solve a number of tasks that presuppose analysis of numerous projects in the context of their content, terms and steps, requirements in different types of resources; alignment of made decisions by directions, intensity and time. Complicated and 
multidimensional character of these tasks defines the necessity to apply the potential of modern computer technologies that requires relevant formalized representation. Representation of processes of realization and management of projects in multidimensional spaces of signs may be the base of such representation.

\section{Conclusion}

Analysis of existing theoretical and applied approaches of system support of the process of project management of social and economic systems allows making conclusion that there are no complex forms, methods and technologies that support the process of decision making that could allow accounting for the following in all management steps:

-features and specifics of system functioning;

-system structure and organizational structure of management as adaptive in relation of immanent changes of internal and external environment;

-target functions of a system as a whole and its separate subsystems;

-parameters of effectiveness of decision making and realization that means support for uninterruptable and adaptive character of decision making;

-multidirectional economic, social and political interests of interacting structural subsystems and systems of external environment;

-system integrity level and the level of interaction of subsystems' modules.

Methodological specifics of methodical and technological support of social and economic system management is that in many cases hierarchial structure of complex system on its own is external environment in the scope of subsystems management, i.e. structural units, areas, economical complexes, industries, viewed in complex systems as independent managed social and economic entities. In this context the main parameters of decision making are the following:

- complexity - number of factors the system should react on;

- interrelation of factors - extent of one factor's impact on the others;

- variability level - the level of changeability of each factor;

- agility - rate of changes in internal and external structure of a system;

- uncertainty - ratio of the volume of information and its soundness, accuracy and sufficiency for making managerial decisions.

Economic stability and effectiveness of complex systems management is follows by the growth of structural organization of a system, changes of quantitative characteristics, constant need to adaptation to external environment. Improvement of system structure in the scope of management process presupposes growth of activity aimed on improvement of its internal environment that support alignment of processes of development of a system and its external environment.

Enhancement of efficiency of managerial decision making and realizationin program and project's dimension requires the following:

-development of adaptive decision making algorithms and programs for a system as a whole and its separate subsystems;

-alignment of interests of managerial process members, structural subsystems in the context of unidirectional definition of objectives;

-working out programs and projects of effective functioning of subsystems in complex economic environment, adaptation of tools of these programs and projects to management process.

\section{References}

Barnes, N. M. L., \& Wearne, S. H. (1993). The future for major project management. International Journal of Project Management, 11(3), 135-142. http://dx.doi.org/10.1016/0263-7863(93)90046-P

Chalenko, A. Yu. Self-organization and entropy in nature and economy. Retrieved March 13, 2014 from http://kapital-rus.ru/articles/article/211036.

Cockshott, P., \& Wright, I. (2009). Probabilistic approach in economy. Information, money and price. Retrieved March 13, 2014, from http://left.ru/2009/2/cockshott184.phtml 
Elazar, L., \& Smith, B. C. (Eds.). (1991). Federal Systems of the World. Retrieved March, 13, 2014, from http://www.scorcher.ru/art/theory/evolition/dissip_sys.php

Gumerova, A. A. (2008). Strategic planning and assessment of regional programs: the experience of Canada. Region: economy and sociology, 2.

Inshakov, O. V. (2003). "The core of development" in the context of the new theory of production factors. Economic science of today Russia, 1 .

Liberzon, V. I. Main concepts and processes of project management. Retrieved March 22, 2014, from http://www.osp.ru

Medvedeva, T. A. (2008). Management of dissipative systems in economy. Economic sciences, 4(41).

Meskendahl, S. (2010). The influence of business strategy on project portfolio management and its success - A conceptual framework. International Journal of Project Management, 8(28), 807-817. http://dx.doi.org/10.1016/j.ijproman.2010.06.007

Morris, P. W. G. (2000). Researching the unanswered questions of project management. Project management research at the turn of the Millennium: Proceedings of PMI Conference.

Prigogine, I., \& Stengers, I. (1984). Order out of chaos, Man's new dialogue with nature. London: Heinemann.

Rodrigues, A. G., \& Williams, T. M. (1997). System dynamics in software project management: Towards the development of a formal integrated framework. European Journal of Information Systems, 1(6), 51-56. http://dx.doi.org/10.1057/palgrave.ejis.3000256

Shekhovtseva, L. S. (2008). Strategic goal-setting of a region as a subject of development. Regional economy: theory and practice, 19(76).

Shevchenko, I. K. (2009). Tools and technological support of the process of social and economic systems management: program and project approach ( $\mathrm{PhD}$ thesis). Rostov-on-Don.

Stepanov, L. V. (2010). Genesis of market system of an enterprise. Management in social and economic systems, 3(46).

Turner, J. R. (1994). Editorial: Project management future developments for the short and medium term. International Journal of Project Management, 12(1), 3-4. http://dx.doi.org/10.1016/0263-7863(94)90002-7

Westerweld, E. (2003). The Project Excellence Model1: linking success criteria and critical success factors. International Journal of Project Management, 21, 411-418. http://dx.doi.org/10.1016/S0263-7863(02)00112-6

Zarubin, V. I., \& Tkhakushinov, E. K. (2014). Management of Innovation Development System of Regional Economic: Project Approach. World Applied Sciences Journal, 30(2), 191-194. http://dx.doi.org/10.5829/idosi.wasj.2014.30.02.14004

Zernadze, A. (2000). Research of system features in economy as prerequisite of overcoming the crisis. Problems of theory and practice of management, 1 .

\section{Copyrights}

Copyright for this article is retained by the author(s), with first publication rights granted to the journal.

This is an open-access article distributed under the terms and conditions of the Creative Commons Attribution license (http://creativecommons.org/licenses/by/3.0/). 